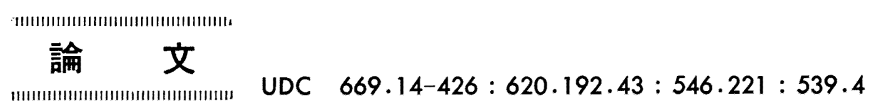

\title{
高炭素鋼の棒材および伸線材における硫化物系
} 介在物の変形挙動と機械的性質への影響*

\author{
金子晃 司**. 开上毅*** \\ 高田寿***.木下修司****
}

\section{Shape Change of Sulphide Inclusions during Hot Bar Forging and Cold Wire Drawing and Its Influence on Mechanical Properties of High Carbon Steels}

\author{
Koji Kaneko, Tsuyoshi Inoue \\ Hisashi TAKADA, and Shushi KINOSHIta
}

Synopsis:

This paper describes the deformation behaviour of sulphide inclusions (MnS) during hot working (forging and rolling) to bar and during cold drawing using high carbon steels.

During hot working to bar, MnS first elongates and then breaks into pieces and each $\mathrm{MnS}$ becomes smaller. On the other hand, sulphide inclusions in REM treated steel remain almost globular during hot working.

On cold drawing, $\mathrm{MnS}$ also becomes smaller due to both deformation and fragmentation. In REM treated steel, however, a large inclusion breaks into clustered pieces while a small inclusion stays globular and causes a crack in the vicinity of the inclusion in the drawing direction.

Mechanical properties of the forged bar are determined in both longitudinal and transverse directions after being normalized at $780^{\circ} \mathrm{C}$. Although the reduction of area of the transverse direction decreases with increasing $\mathrm{S}$ content, the effect of $\mathrm{S}$ content decreases with the increases of the hot forging ratio.

$\mathrm{Up}$ to $70 \%$ drawing reduction, an increase of $\mathrm{S}$ content decreases the ductility in the transverse direction of cold drawn steel, but over $70 \%$ the effect of $\mathrm{S}$ content disappears because the ductility is very poor.

It is found that there is a correlation between the fracture strain and the sulphide inclusion area fraction on the fracture surface of tensile test pieces. This relation is maintained regardless of the amount and the shape of the sulphide inclusion, or of the test direction.

However, the fracture strain of cold drawn steel, of over $70 \%$ drawing reduction, is determined mainly by the fiber structure of the matrix, caused by the severe drawing, and the above relationship disappears.

\section{1. 緒}

言

鋼中の非金属介在物は機械的性質や疲労特性に影響す ることがよく知られている1)2 . 特に MnS は熱間圧延 中に伸長 ( $\left.{ }^{3)} \sim 5\right)$ ，鋼板の板厚方向の延性を極端に劣化す るため，鋼板中の $\mathrm{MnS}$ の変形挙動や機械的性質に打よ ぼす影響については多くの報告がなされている6) 8)，し
かし高炭素鋼の棒鋼や伸線材に括いては，一般に伸長し た $\mathrm{MnS}$ の影響の少ないと思われる長手方向（圧延また は伸線方向）の機械的性質が重要視されているので, 棒 鋼や伸線材に打ける硫化物系介在物の変形挙動はあまり 検討されていない，しかし，近年，中村ら9)によつて高 炭素鋼の伸線材の引張強さや絞りは $\mathrm{S}$ 量や $\mathrm{P}$ 量の影響を 受けないが，曲げ試験や圧縮試験を行うと $\mathrm{S} の$ 影響があ

* 昭和 53 年 10 月本会講演大会にて発表 昭和 54 年 5 月 14 日受付 (Received May 14, 1979)

** (株) 神戸製鋼所 中央研究所 (Central Research Laboratory, Kobe Steel, Ltd., 1-3-18 Wakihama-cho Fukiai Kobe 651)

*** (株) 神戸製鋼所中央研究所 工博 (Central Research Laboratory, Kobe Steel, Ltd.)

**** (株) 神戸製鋼所高砂工場 工博 (Takasago Works, Kobe Steel, Ltd.) 
Table 1. Chemical composition (\%).

\begin{tabular}{l|c|c|c|c|c|c|c}
\hline Steel & $\mathrm{C}$ & $\mathrm{Si}$ & $\mathrm{Mn}$ & $\mathrm{P}$ & $\mathrm{S}$ & $\mathrm{Al}$ & $\mathrm{Ce}$ \\
\hline W 1 & 0.78 & 0.30 & 0.76 & 0.008 & 0.006 & 0.004 & - \\
W 2 & 0.70 & 0.27 & 0.77 & 0.011 & 0.009 & 0.004 & - \\
W 3 & 0.74 & 0.28 & 0.77 & 0.012 & 0.018 & 0.004 & - \\
W 4 & 0.74 & 0.27 & 0.76 & 0.010 & 0.047 & 0.002 & - \\
W R & 0.74 & 0.29 & 0.77 & 0.010 & 0.006 & 0.028 & 0.020 \\
\hline
\end{tabular}

らわれることが示され，伸線材においても試験方法や破 壊方向によつて硫化物系介在物の影響があらわれること を示唆した。

本稿は，棒鋼に熱間加工あるいは伸線する過程で硫化 物系介在物がどのよらに変形挙動をするかを明らかに し，さらに機械的性質にどのように影響しているか検討 した結果である。

\section{2. 実 験 方 法}

\section{$2 \cdot 1$ 供試材}

ピアノ線材 SWRH 72B を基本成分として高周波炉 で溶解し， $90 \mathrm{~kg}$ の鋼塊をつくつた. 化学組成をTable

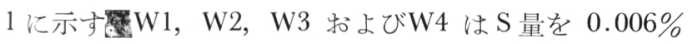
から $0.047 \%$ の範用で変化させたもので,WRは硫化物 系介在物の形状制御を行らために, $\mathrm{Al}$ 添加後に希土類 元素をミッシュメタルで添加したものである. $90 \mathrm{~kg}$ 鋼 塊の平均直径は $180 \mathrm{~mm}$ であり, これを $1200^{\circ} \mathrm{C} て ゙ 2$ $\mathrm{h}$ の溶体化後, 鍛造により $50 \mathrm{~mm}$ 角, $25 \mathrm{~mm}$ 丸, 13 $\mathrm{mm}$ 丸, $8 \mathrm{~mm}$ 丸の棒材に加工した.

\section{$2 \cdot 2$ 冷間伸線}

各供試材のミクロ組織をとろえるため, $780^{\circ} \mathrm{C} て ゙ 1 \mathrm{~h}$ の焼ならし処理をして， $25 \mathrm{~mm}$ 丸材を $24 \mathrm{~mm}$ 丸に機 械加工後, 冷間伸線に供した. 伸線材の直径の変化は以 下のと拈りである。

$24 \mathrm{~mm}-21.22-18.01-15.50-13.05-11.13-9.82$

$-8.62-7.65-6.82-5.92-5.11-4.25$

直径が $10 \mathrm{~mm}$ 以上の場合にはリーレ万能引張試験機 で, $10 \mathrm{~mm}$ 以下の径のものはドローベンチで伸線した. 伸線速度は前者に执いては $50 \mathrm{~mm} / \mathrm{min}$, 後者は $1 \mathrm{~m} / \mathrm{min}$ である。

\section{$2 \cdot 3 \mathrm{MnS}$ の形状変化の測定}

$\mathrm{S}$ の多いW 3 とW 4 の鍛造材に拈いて, 長手方向に平 行な断面の研磨面上で 400 倍めるいは 800 倍の写真撮影 を行い，拡大鏡で観察して棈円状になつた MnS の長軸 (a) と短軸 (b)の長さを測定した. 測定数は各サイズの 鍛造材について約 25 個である. Photo. 1 はW 4 の 50 $\mathrm{mm}$ 角材に括ける介在物であり, 他の供試材の $\mathrm{MnS}$ も このように密集している場合が多く，供試材の酸素量や

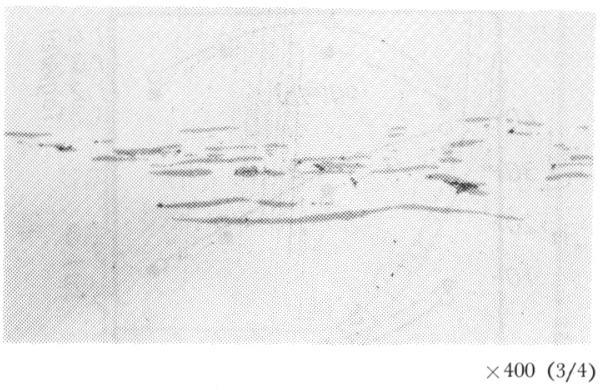

Photo. 1. MnS inclusions in forged steel bar W4.

合金元素量も少ないことから, Sims の分類10)では Type IIに属するものと考学られる.この場合鍛造方向に対し 極端に傾いている介在物は少なかつたので, 伸長した $\mathrm{MnS}$ の先端間距離を長軸 $(\mathrm{a})$, 太くなつている部分を 短軸 ( b ) として各介在物の長, 短軸比の対数 $\log (\mathrm{a} / \mathrm{b})$ を計算し，兵の平均を介在物形状係数とした.

供試材W 4 の伸線材についても, 伸線方向と平行な断 面の研磨面上で観察される $\mathrm{MnS}$ の長軸, 短軸を鍛造材 と同様の方法で測定した.

\section{$2 \cdot 4$ 材料試験}

$25 \mathrm{~mm}$ 丸, $13 \mathrm{~mm}$ 丸, $8 \mathrm{~mm}$ 丸に鍛造した供試材を $780^{\circ} \mathrm{C}, 1 \mathrm{~h}$ の焼ならし処理でミクロ組織を均一にした後 丸棒中心部から鍛造方向（たて方向）と直角方向（よこ 方向）に引張試験片を採取した. 試験片は平行部直径 $1.0 \mathrm{~mm}$, 平行部長さ $3.0 \mathrm{~mm}$ の小さいものである. イ ンストロン引張試験機で $0.5 \mathrm{~mm} / \mathrm{min}$ の引張速度で試 験をした. 伸線材についても線材中心部から同様の引張 試験片を伸線方向（たて方向）と直角方向（よこ方向） から採取し, 試験した. 引張試験前後の直径を工具顕微 鏡で測定し，絞り值を求めた。な扣伸線材は非常に硬く なつているため, 引張試験片加工時の発熱による温度上 昇には特に注意をはらつた。

引張試験後, X線マイクロアナライザで破断面上の $\mathrm{S}$ と Al の特性X線像を 500 倍で 5 10 視野撮影し, 破 面上に占める硫化物系介在物とアルミナ系介在物の面積 率を測定した しかし, アルミナ系は非常に少なかつた ので, 硫化物系介在物をもつて破面上の介在物面積率と した。

\section{3. 実験結果および考察}

\section{$3 \cdot 1$ 熱間加工中の $\mathrm{MnS}$ の変形挙動}

供試材W3，W 4 を鍛造した際の楕円状 MnS の長軸 (a) 短軸 $(\mathrm{b})$, 介在物形状係数 $\log (\mathrm{a} / \mathrm{b})$ 扣よび清浄度 の変化を熱間加工比に対し Fig. 1 に示す. ここで熱 間加工比とは鋼塊の横断面之鍛造後の 横断面の面積比 


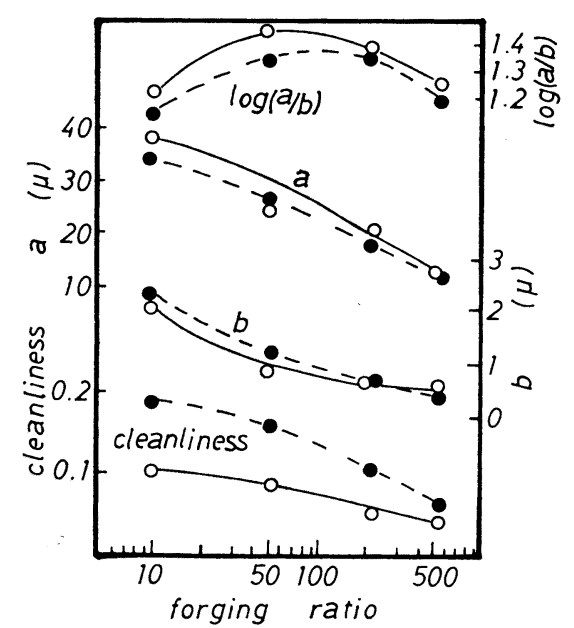

Fig. 1. Effect of hot working (forging) ratio on deformation and cleanliness of $\mathrm{MnS}$ in steel bar $\mathrm{W} 3(\bigcirc)$ and $\mathrm{W} 4(0)$. a and b are major and minor axes of eliptical $\mathrm{MnS}$. Initial ingot size is about $180 \mathrm{~mm}$ in diameter.

$\left(A_{\mathbf{0}} / A\right)$ である. 熱間加工比の増加とともに $\mathrm{MnS}$ の長 軸 $(\mathrm{a})$ も短軸 $(\mathrm{b})$ も小さくなつているが, $\log (\mathrm{a} / \mathrm{b})$ の変 化は比較的小さい. 短軸が減少しているといらことは, $\mathrm{MnS}$ が鍛造中に変形し鍛造方向に伸ばされ細長くなつ ていることを示している. 一方長軸も熱間加工比の増大 で減少してくるが，熱間加工前の MnS を球として，加 工中に鋼と同程度の变形をしたと仮定して，熱間加工比 10 の $\mathrm{MnS}$ の短軸 $2 \sim 2.5 \mu \mathrm{m}$ から熱間加工前の $\mathrm{MnS}$ の 大きさを推定すると約 $7 \mu \mathrm{m}$ にすぎない。ところが熱間 加工比 10 に抢ける $\mathrm{MnS}$ の長軸は $30 \mu \mathrm{m}$ 以上あること から明らかに鍛造中に伸長したことを示している.どの 程度の熱間加工比で $\mathrm{MnS}$ が最も長くなるかは明らかで ないが，棒材に熱間加工中においても熱間加工比が比較 的少ない場合は長くなる. しかし熱間加工比が 10 より 大きくなつてくると分断の頻度が多くなり，変形はして いても長くならないものと考えられる.

次に清浄度であるがW 3，W 4 の供試材ともに熱間加 工比の增大とともに清浄度の低下がみられる．熱間加工 中に介在物が増減することは考えにくいので， MnS の 変形と分断で個々の介在物の大きさが小さくなり, 光学 顕微鏡での観察が困難になつて見かけ上，清浄度の減少 につながつたものと考えられる。

また鍛造工程に拈いては，鍛造中に試料の温度が下が ると再加熱するため，それによる $\mathrm{MnS}$ の分断もあると 考えられる. そこで工場で压延した棒状に抢ける $\mathrm{MnS}$ の形状変化を調查した．鋼種は $\mathrm{S} 50 \mathrm{C}$ ，鋼塊の平均サイ

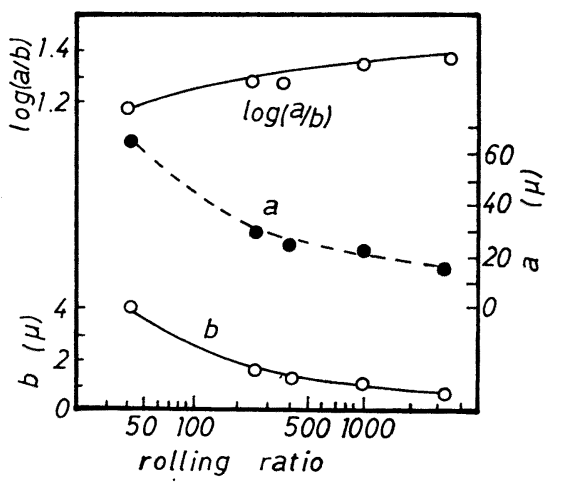

Fig. 2. Effect of hot working (rolling) ratio on the length of major (a) and minor (b) axes of $\mathrm{MnS}$ in mill rolled steel bar. Starting ingot size is about $700 \mathrm{~mm} \mathrm{squ}-$ are.

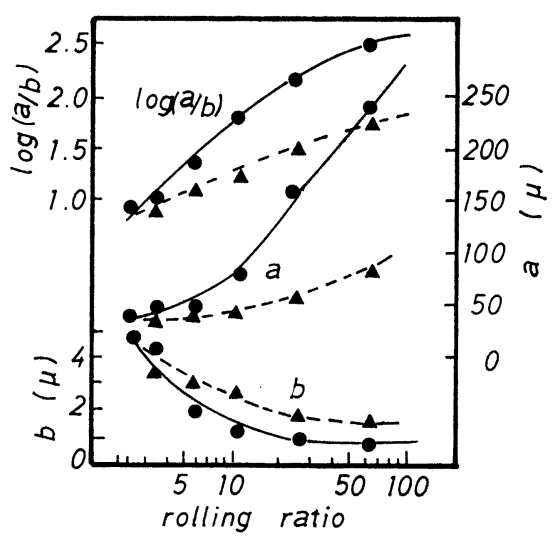

Fig. 3. Effect of working (rolling) ratio and temperature on the length of major (a) and minor (b) axes of eliptical $\mathrm{MnS}$ in rolled steel plate.

: $780^{\circ} \mathrm{C}-900^{\circ} \mathrm{C}$ rolling

$\Delta$ : $1100^{\circ} \mathrm{C}-1250^{\circ} \mathrm{G}$ rolling

ズは約 $700 \mathrm{~mm}$ 角で, $110 \mathrm{~mm}$ 角のビレットに分塊後 加熱して $50 \mathrm{~mm}$ 丸， $40 \mathrm{~mm}$ 丸， $25 \mathrm{~mm}$ 丸に圧延した ものである. MnS の形状測定方法は鍛造材と同じであ る. 熱間加工比（圧延前後の横断面の面積比）に対しプ ロットした結果を Fig. 2 に示す. 压延途中で再加熱を おこなわない工場の圧延材においても鍛造材と同様に $\mathrm{MnS}$ の変形による短軸 (b) の減少とともに長軸 ( a )の 減少もみられる。このよらな棒材の熱間加工中における $\mathrm{MnS}$ の変形挙動は，今まで多くの報告がなされている 鋼板の熱間圧延過程で観察される場合と異なつている. 比較のため，鋼板に圧延中 $\mathrm{MnS}$ はどのような形状変化 をするか Fig. 3 に示す. これは工場で分塊した $0.13 \%$ $\mathrm{C}-0.24 \% \mathrm{Si}-1.34 \% \mathrm{Mn}-0.017 \% \mathrm{~S}-0.027 \% \mathrm{Al}$ の成分を 
有する $300 \mathrm{~mm}$ 厚のスラブから $130 \mathrm{~mm}$ 厚, $110 \mathrm{~mm}$ 幅, $130 \mathrm{~mm}$ 長さの試料を採取して実験室で压延し, MnS の形状変化を調べたものである. 高温压延とは $1100^{\circ} \mathrm{C}$ から $1250^{\circ} \mathrm{C}$ の温度範囲で圧延したもので, 低温圧延之 は $780^{\circ} \mathrm{C}$ から $900^{\circ} \mathrm{C}$ の温度範囲で压延したものであ る. 熱間加工比性鋼塊の厚さ $t_{0}$ 之圧延後の板厚 $t$ の比 $t_{0} / t$ であり,幅方向のひろがりは小さいので断面積比に 類似したものである.

鋼板に圧延の場合，圧延温度によつて変形挙動に差は あるが，いずれにしても熱間加工比が増すと $\mathrm{MnS}$ は変 形し，長軸 ( a ) は長くなつて低温圧延では数百ミクロン にもなつている・分断が少なければ $\mathrm{MnS}$ は伸長して介 在物形状係数 $\log (\mathrm{a} / \mathrm{b})$ 6大さくなる.

このように鋼板の圧延中と異なつて棒鋼の熱間加工の 場合, $\mathrm{MnS}$ は変形だけでなく分断も行われて，個々の 介在物は小さくなつて介在物の形状係数の変化も少ない ことが特徴である.

シリケート系の介在物が熱間圧延中に分断することは 知られているが1112)，MnS の分断に関する報告はみあ たらない. BAKER ら ${ }^{3)}$ は圧延比を大きくしていくと $\mathrm{MnS}$ の相対変形能が減少してくるという結果を示して いる.しかし彼らの測定方法は介在物の単位面積当たり の総長さを求めているため分断が扣こなわれているかど らかの判定はできない。下畑ら ${ }^{13)}$ は $\mathrm{S}$ 快削鋼を熱間圧延 し, 压延方向に平行な板厚方向の断面で観察される硫化 物系介在物の個数の増加割合を求めている. その結果を Fig. 4 に示す 熱間加工比（圧延比）が増大し，50 以上 になる之個数の増加が急激になつて特り，鋼板の圧延に 打いてもその圧延比が大きくなると分断が行われること を示している.

以上のことから棒材においても板材に括いても熱間加

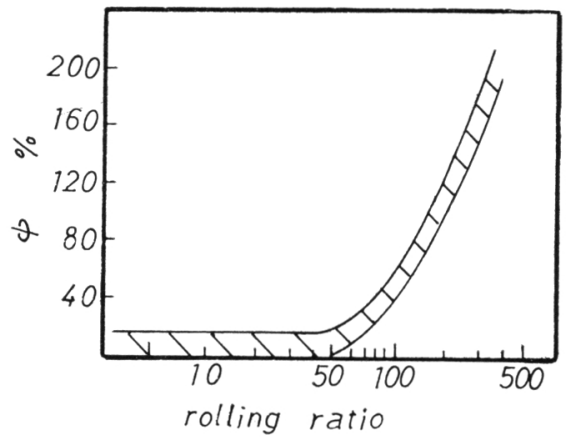

Fig. 4. Relationship between rolling ratio and increasing rate $(\psi \%)$ of the number of of $\mathrm{MnS}$ observed on the polished surface. $\psi=\frac{N-N_{0}}{N_{0}} \times 1000$ $N_{\mathbf{0}}$ : initial number of $\mathrm{MnS}$ $N$ : number of $\mathrm{MnS}$ after rolling

工比の少ない場合は，変形によつて $\mathrm{MnS}$ は長くなつて くるが，熱間加工比を増大させていくと分断が行われる よらになつてあまり長い介在物にならないものと考光ら れる、鋼板に抢いてはそれ程大きい熱間加工比を与えた 調査が少ないため，分断が明確でなかつたが，棒材に おいては熱間加工比を非常に大きくすることが可能であ り，分断現象が明らかになつたものであろら。

一方 REM を添加した WR 材に打いては, 硫化物系 介在物は変形せず, 球状のものが多く観察され, 棒材の 熱間加工に扣いても介在物の形状制御に有効な添加元素 であることが確認された。

\section{2 冷間伸線中における介在物の変形挙動}

Photo. 2 は W 4 材に $83 \%$ の伸線加工を与穴た後 (9.82mm 丸) の長手方向の研磨面上で観察される $\mathrm{MnS}$ で，細長く変形しているものや分断によつて短い介在物

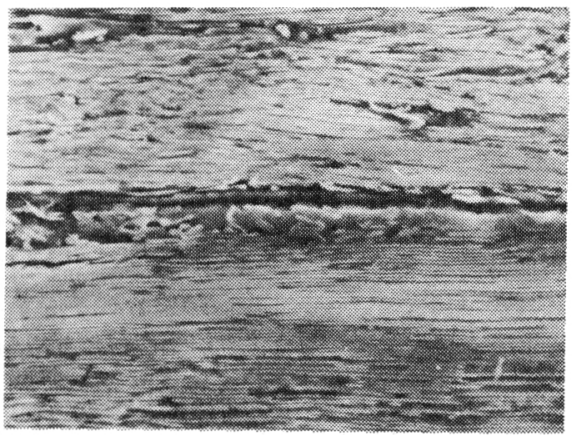

(A) elongated MnS

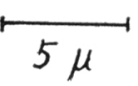

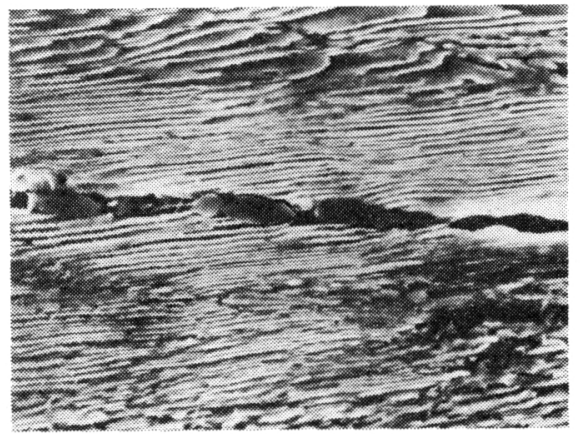

(B) separated $\mathrm{MnS}$

Photo. 2. Scanning electron micrograph of $\mathrm{MnS}$ in steel W4 drawn to $83 \%$. 
になつて並んでいるものがみ壳る Fig. 5 は $24 \mathrm{~mm}$ 丸 から伸線したW 4 材の MnS の形状変化を示したもので

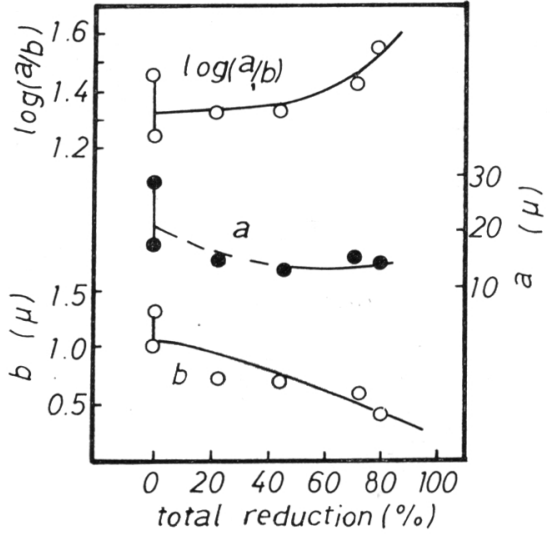

Fig. 5. Effect of total reduction, by drawing, on the length of major (a) and minor (b) axes of eliptical $\mathrm{MnS}$ in cold drawn steel W4.

ある・伸線加工率を増大すると $\mathrm{MnS}$ の長軸( a) はわず かに短くなり，短軸(b)は約 $80 \%$ の伸線加工率で半分 以下になつている。このことは MnS は伸線中に変形之 同時に小さく分断していることを示している.

以上のような研磨面での観察結果をららづけるために よこ方向の引張破断面に拈ける MnS を Photo. 3 に示 す. 伸線加工率が $22 \%$ と少ない場合, Photo. 3(a) に 示すごとく破壞した介在物もあるが，比較的大きく長い 介在物がみられる。さらに伸線加工率を増し，79\%にな ると Photo. 3(b)のように数ミクロンの小さな介在物 に分断されているものが大多数になつてくる. 破断面上 で観察される介在物は伸線加工中でなく，引張試験中に 分断されたといら疑いもある. しかし引張試験中の分断 ならば，絞り值の大きい伸線加工率の少ない万が分断し やすくなるが，実際は絞り值の少ない，伸線加工率の大 きい破断面上で多くの分断が観察されることから，これ らの介在物の 分断は伸線過程で生じたものと考えられ る.

伸線加工率がさらに増大し, $90 \%$ 以上になると, Photo. 3 (c)のよらになり, 破断面での介在物の存在状態は不 明瞭になつてくる.

冷間加工でも鋼板に圧延した場合， MnS は変形し， 長く伸びることが Gove14)らによつて報告されている. 伸線に招いても棈円状 $\mathrm{MnS}$ の短軸が短くなることから 変形していることを示している. しかし圧延に比較して 伸線の場合，伸線方向に強い引張応力が働いていること や，伸線前の MnS がすでに伸長していたことなどが分

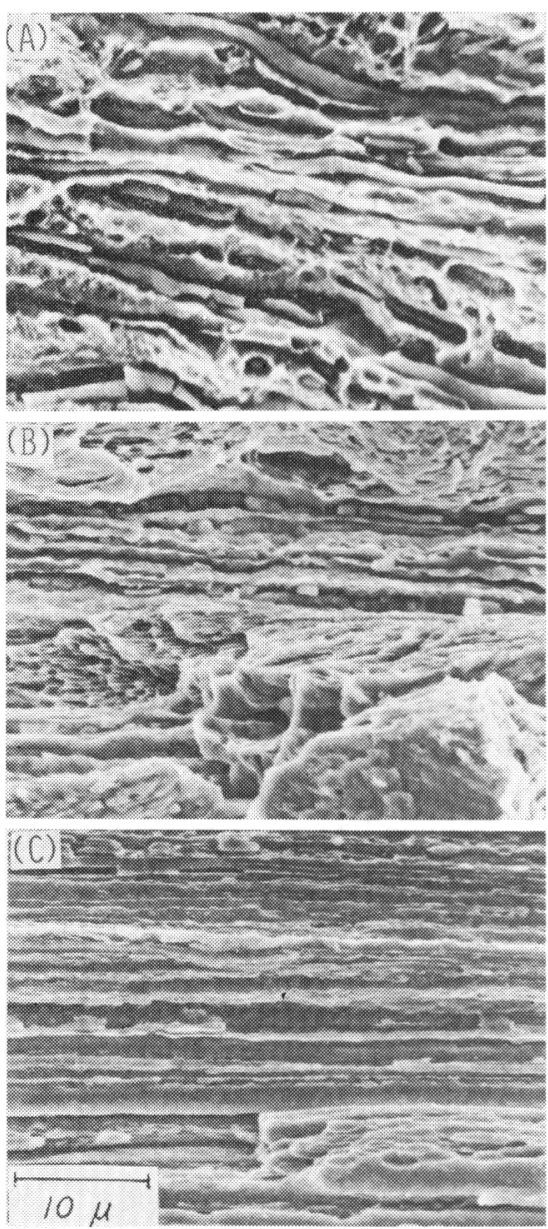

$\begin{array}{llll}\text { (A) } 22 \% \text { drawn } & \text { (B) } 97 \% \text { drawn } & \text { (C) } 94 \% \text { drawn }\end{array}$

Photo. 3. Fracture surfaces of transverse tensile specimens of steel W4 drawn to various drawing reduction. Size of broken pieces of inclusions becomes smaller and invisible as drawing reduction increases.

断を容易にしたものと考觉られる.

次に REM 系介在物の伸線中に拈ける挙動を述べる. 伸線前に球状を呈していた介在物は，伸線することによ つて Photo. 4 のように破壊されて伸線方向に並九でく る. 倍率 400 倍以下の光学顕微鏡では JIS に規定され ているA系介在物のように観察されるが，電子顕微鏡に よる高倍率観察ではこのように塊状の小さい介在物が並 んでいるのがわかる. Photo. 5 は WR 材の伸線加工 率 79\%のよこ方向破断面であるが，伸線中に破壊した 小さな塊状介在物が伸線方向に並んでいる. 一方 $83 \%$ の伸線をしても比較的小さい介在物は Photo. 6 のよ らに破壊せず，球状のままで存在している。 そして， GOVE ら ${ }^{14)}$ が冷間圧延材に扔いて硬い介在物があると圧 
延方向に細いクラックがでさているといつているのと類 似のクラックが伸線方向に伸びているのがみえる.

Photo. 7 は 70\%の伸線をしたWR 材を再び $780^{\circ} \mathrm{C}$ で $1 \mathrm{~h}$ 加熱して焼ならし処理した組織である．伸線方向 に並んだセメンタイト層は再びランダム方向のパーライ 卜組織になり，さらに Photo. 6 のような球状介在物の 周辺の小さなクラックは消失している。 これは高温に物 けるマトリックスの自己拡散 ${ }^{15)}$ によるものと考光られ る.

\section{3 機械的性質}

Fig. 6 に鍛造材の焼ならし処理後の機械的性質を $\mathrm{S}$ 量

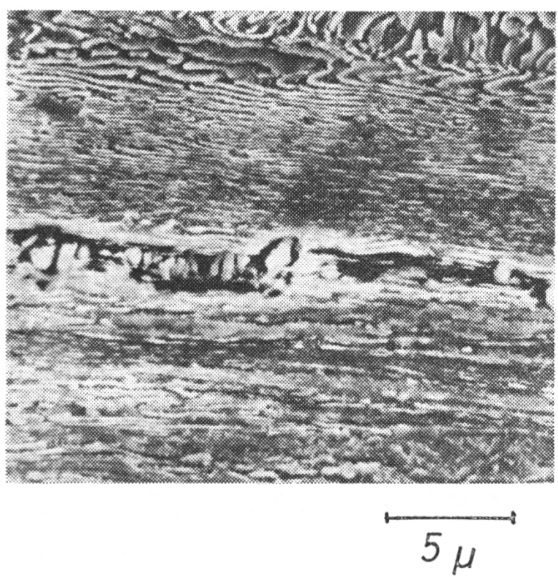

Photo. 4. Scanning electron micrograph of a cluster type inclusion of steel WR drawn to $83 \%$. Relatively large inclusions of REM treated steel breaks into pieces during cold drawing.

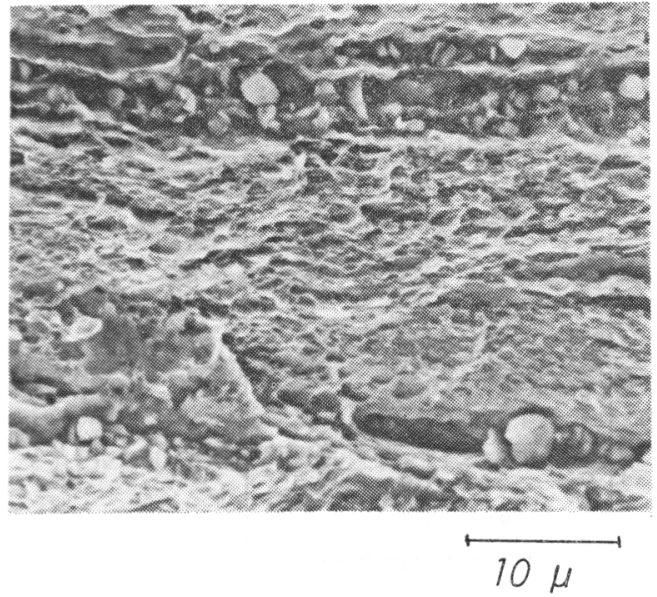

Photo. 5. Scanning electron micrograph of cluster type inclusions on the fracture surface of transverse tensile specimen of steel WR drawn to $83 \%$.
に対し示し，Fig. 7 には熱間加工比に対して示した. 引 張強さは線径が細くなるにつれてわずかに高くなつてい るが，これは燒ならし処理中の冷却速度に起因するもの と考学られる. Fig. 6 で $\mathrm{S}$ 量が増してもたて方向の絞り 6変化は少ないが，よこ方向の絞りの低下が大きいそ して熱間加工比の少ない $25 \mathrm{~mm}$ 丸材より熱間加工比の 大きい $8 \mathrm{~mm}$ 丸材の方が $\mathrm{S}$ の影響は軽減されている.こ の現象は圧延比を大きくすることによつて $\mathrm{MnS}$ が伸長 し，ょこ方向や板厚方向の延性の劣化が大きい鋼板の圧 延材で観察される結果と逆になつている.この原因は前 に述べたように棒鋼の場合には熱間加工比の増加ととも に介在物が分断し，介在物の形状係数ががつて小さく なる現象と関連していると考光られる．Fig.7で S 量の 少ないW 1 材や REM 添加した WR 材は熱間加工比 $50(25 \mathrm{~mm}$ 丸) から $500(8 \mathrm{~mm}$ 丸) に増すと, よこ方向 絞りは $5 \%$ 程度の改善しかないが， $\mathrm{S}$ 量の多いW 3 は

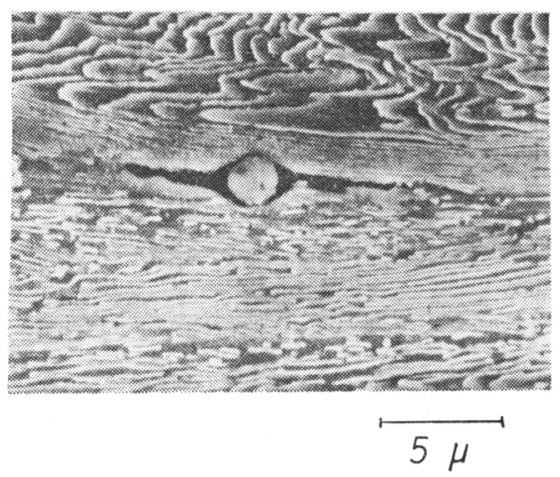

Photo. 6. Scanning electron micrograph showing a crack in the vicinity of a small globular inclusion which remained unbroken in steel WR drawn to $83 \%$.

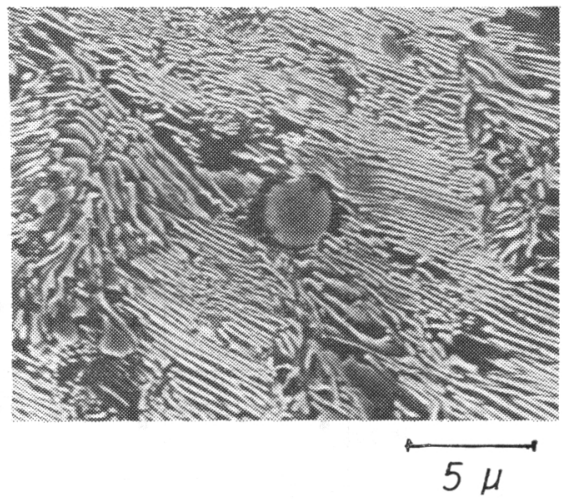

Photo. 7. Scanning electron micrograph of a globular inclusion of steel WR normalized at $780^{\circ} \mathrm{C}$ after $79 \%$ drawing. The crack as shown in Photo. 6 disappears during normalizing treatment. 
$11 \%$ ，さらに多いW 4 は 15\%以上も改善されている. すなわち硫化物系介在物の量や形状の影響の少ない供試 材では熱間加工比の影響が少なく， $\mathrm{S}$ 量の多い場合に熱 間加工比の影響が大きくなる：このことは熱間加工比の 少ない場合は比較的大きい $\mathrm{MnS}$ が伸長しているため, よこ方向の絞りを劣化させる原因になつているのに対 し，熱間加工比を増大していくと， MnS は変形と同時 に分断されて個々の $\mathrm{MnS}$ は小さくなり, 介在物の形状 効果も少なくなつてよこ方向の絞りの劣化が軽減され, その結果 $\mathrm{S}$ 量の多いW 3,W 4 のよこ方向絞りを改善し たものと考えられる. 要するに棒鋼に括いては熱間加工 比の小さい場合の方が大きい伸長した $\mathrm{MnS}$ があるた め，よこ方向の延性を劣化させるようになり，よこ方向

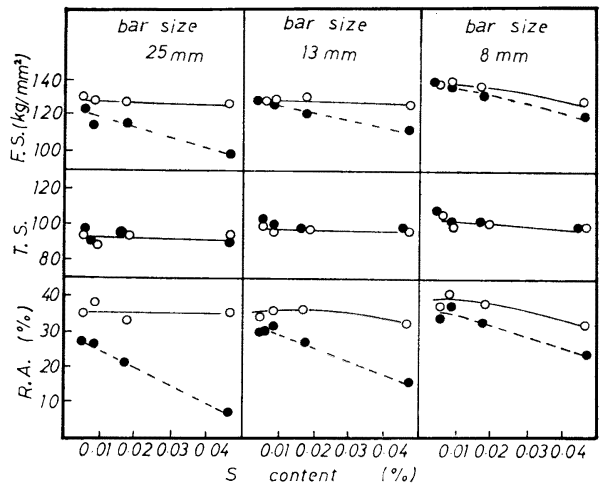

Fig. 6. Influence of $\mathrm{S}$ content on the mechanical properties of steel bar normalized at $780^{\circ} \mathrm{C}$. F.S. : fracture stress, T.S. : tensile stress, R.A. : reduction of area, $\bigcirc$ : longitudinal - : transverse.
の延性が必要な場合は $\mathrm{S}$ の低減が必要である．一方熱間 加工比の大きい細径の棒鋼になると $\mathrm{MnS}$ は分断されて よこ方向の延性にあまり影響しなくなるため，太径のと きにくらべて S の低減に注意しなくてもよいようにな る. したがつて REM などの添加による形状制御の効果 も板材ほど顕著でなくなつてくる.

次に，伸線後の機械的性質についてみると，その挙動 は各供試材とも大きな違いはないので，W 1 とW4のた て方向，よこ方向の性質について Fig. 8 に示した た て方向の 破断応力は伸線加工率とともに上昇するが, $70 \%$ 以上になるとその上昇率が大きくなつてくるよこ 方向破断応力は伸線加工率の影響をあまり受けないが， $70 \%$ のところでわずかに隇少し, それ以上の伸線加工率 でわずかに増加傾向にある. 引張強さはたて方向，よこ 方向とも漸増しているが，70\% 前後の伸線加工率で変化 がみられる.しかしよこ方向は伸線加工率を増してくる と最高荷重点に達する前に破断するようになり，たて方 向との差は大きくなつてくる，たて方向絞りは伸線加工 率の少ない段階で減少し, 伸線加工率 60〜70\% のとこ ろで伸線前の約半分の最低絞り值になり，それ以上の伸 線加工率で再び回復してくる.よこ方向絞りは 70\% で急激に減少し，それ以上の伸線加工率ではほとんど絞 りのない破断をする. 以上のように伸線加工率が $70 \%$ 前後で機械的性質の変化があり，加工率 $70 \%$ まではパ ーライト中のセメンタイトが回転して伸線方向に並ぶ段 階であり，加工率 $70 \%$ 以上はほとんどセメンタイトが 並んだ領域であると考えられる.

硫化物系介在物の影響を受けやすいのはよこ方向の絞

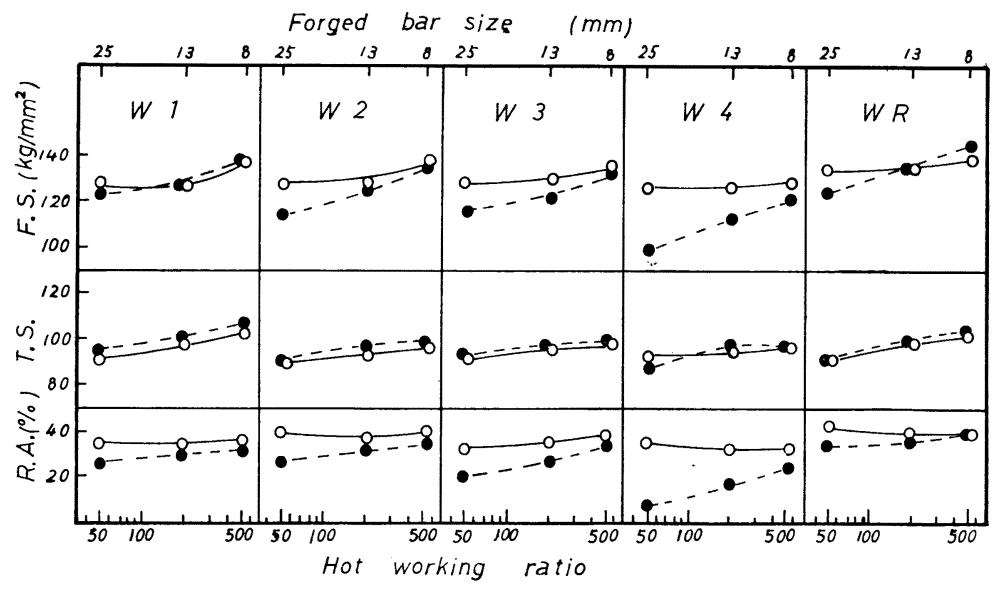

Fig. 7. Effect of hot working (forging) ratio on the mechanical properties of steel bar normalized at $780^{\circ} \mathrm{C}$.

$\bigcirc$ : longitudinal

: transverse. 


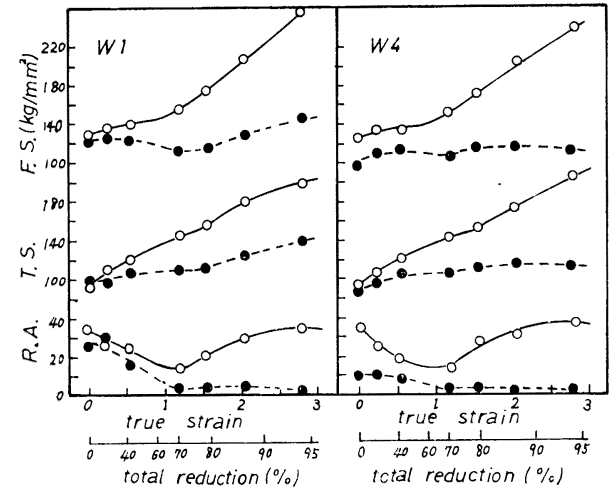

Fig. 8. Effect of cold drawing on the mechanical properties of longitudinal $(O)$ and transverse (O) directions of steel $\mathrm{W} 1$ and $\mathrm{W} 4$.

りである. S 量との関係を Fig. 9 に示す. 伸線前ある いは低伸線加工率に拈いては S 量の増加でよこ方向絞り は減少しているが，伸線加工率が $70 \%$ を越えるとセメ ンタイト層が伸線方向に並んで，介在物の少ない供試材 もよこ方向絞りを劣化し， $\mathrm{S}$ 量の影響が小さくなつてく る.

\section{4 破断面上に占める介在物面積率と絞りの関係}

破断面上を走査型電子顕微鏡で観察すると, 研磨面上 の何十倍もの介在物がみられる. これは破壊が介在物に 沿つて進行しているためで, 鋼板の延性 ${ }^{16)}$ (破断歪やシ ヤルピー值）は破面上に占める介在物の面積率とよい相 関にあることは前報に示した5)8)。棒材および伸線材の 引張破断歪との関係をプロットした結果を Fig. 10 に 示す. 破断歪 $(\varepsilon)$ と絞り $(\rho)$ の間には $\varepsilon=\ln \{1 /(1-$ の)\}の関係がある.

伸線前の Fig. 10 ( a ) は, 供試材中の $\mathrm{S}$ 量やたて方 向，上こ方向の破断方向や， REM 添加の有無に関係な く破断歪は破面上に占める介在物面積率とよい相関をも つていて，その面積率が増すと破断歪も減少している. 伸線加工率の低いFig. 10(b)，Fig. 10(c) において は破面上の介在物面積率が少なくなつても伸線前の破断 歪にならず，マトリックス自身の延性が低下しているこ とを示し， $\mathrm{S}$ 量や破断方向に関係なく整理できる. とこ ろが 70\% 以上の伸線加工率になると様子が異なつてき て，Fig. 10(d)の70\% 伸線材ではたて方向とよこ方向 で別々の関係になり，79\% 伸線材では Fig. 10(e) の ようにまつたく相関がなくなつている.しかし 70〜79\% の伸線材を再び $780^{\circ} \mathrm{C} 1 \mathrm{~h}$ の焼ならし処理で伸線前と 同じ組織にしてから引張試験をすると，Fig. 10(f) の ように伸線前と類似の関係まで回復した. 以上のことか ら，伸線前や伸線加工率の少ない場合において，延性破

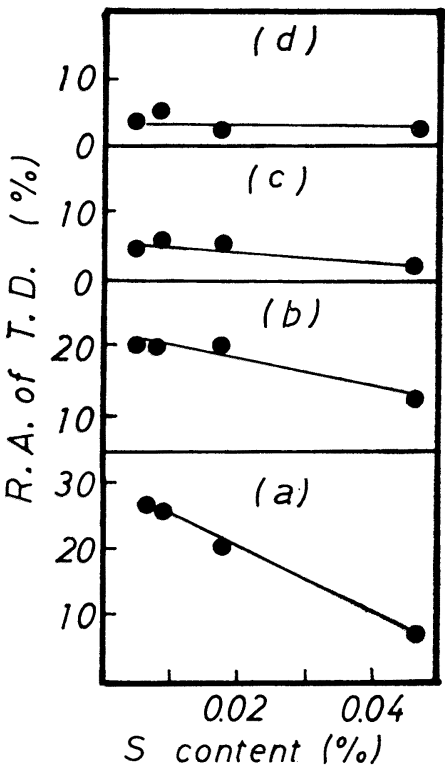

Fig. 9. Influence of $\mathrm{S}$ content on the reduction of area in transverse direction of steel W4 (a) : normalized (b) : 44\% drawn (c): $70 \%$ drawn (d) : $94 \%$ drawn.

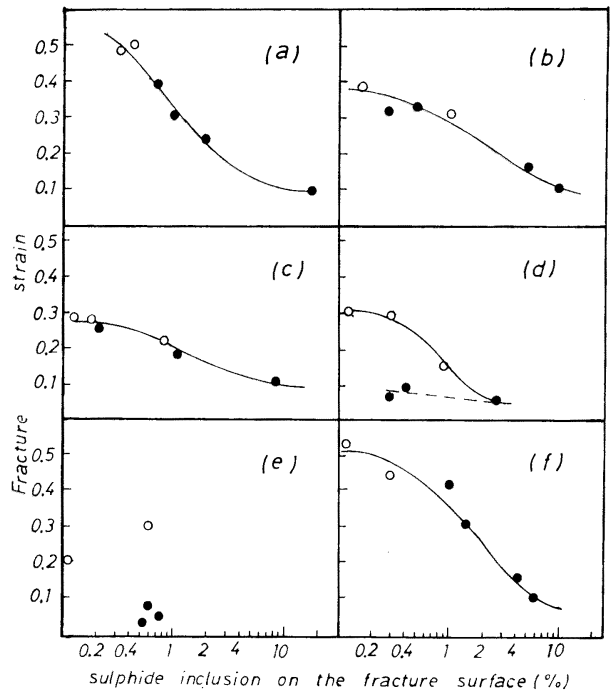

Fig. 10. Relationship between fracture strain and sulphide inclusion area fraction on the fracture surface.

(a) : normalized (b) : 22\% drawn (c) : 44\% drawn (d) : 70\% drawn (e) $79 \%$ drawn (f) : normalized after $70 \%$ or $79 \%$ drawn $\bigcirc$ : longitudinal $\bigcirc$ : transverse.

壊は介在物の周辺に発生したボイドの連結で進行し17), 破断歪はマトリックス自身の延性を介在物がどの程度劣 
化するかで決定される，したがつて伸線によつてマトリ ックス自身の延性が低下すると，介在物の影響の少ない 場合でも，すなわら破面上の介在物面積率が少なくても 延性は小さくなる.さらに伸線率が高くなるとパーライ ト中のセメンタイト層は伸線方向に並び，フェライト層 は集合組織が発達して介在物に関係なく破断しやすくな る. その結果, 組織の影響が大きくなつて介在物の影響 は組織のそれに比較して小さくなつてしまうと考えられ る. しかし硬い介在物があれば Photo. 6 のように伸線 方向にクラックを発生し， MnS のよらに変形と分断を しているような介在物においても分断したところではや はりせまいクラックが伸線中に発生していることが推察 されるため, 伸線方向へのクラックの伝播に悪影響する ものと考えられる. 再焼ならし処理で伸線前と類似の関 係に回復したことは伸線過程におけるたて方向絞の劣化 と改善，およびよこ方向絞りの極端に悪くなる現象が組 織や，介在物を起点とした狭いクラックに原因している ことをららづけている.

\section{4. 結}

\section{言}

高炭素鋼を用い，棒材に熱間加工（鍛造，圧延）およ び伸線を行つた際に生じる硫化物系介在物の变形挙動と 微小引張試験片でたて方向, よこ方向の機械的性質を調 查して次の結果を得た.

1) 棒状に熱間加工すると $\mathrm{MnS}$ は板材に圧延中のよ らな変形によつて長く伸ばされるだけでなく，分断も特 こなわれて個々の介在物は小さくなつてくる.この分断 は熱間加工比（加工前後の断面積比）が 10 程度ではじ まり，板材の場合（熱間加工比 50 以上といわれる）よ りも早く分断の傾向があらわれる.

2 ）熱間加工比を大きくすると，分断で個々の $\mathrm{MnS}$ は小さくなるため，よこ方向絞りは熱間加工比を大きく することによつて，かえつて改善される。

3 ) 伸線中においても $\mathrm{MnS}$ は変形だけでく分断もお こる. REM 添加材においては, 大きい介在物は破壊し て塊状の小さな介在物となつて伸線方向に並び，小さい 介在物は破壊せず，伸線方向に狭いクラックをともなつ ている.
4 ）伸線前や，伸線加工率の少ない場合の破断雨は， $\mathrm{S}$ 量や，たて方向よこ方向の試験方向に関係なく,さら に REM 添加の有無にも無関係に破断面上に占める介 在物 (疏化物系) 面積率で整理できることから, 絞りは マトリックス自身の延性を介在物の存在でどの程度劣化 させるかといらことで決まつてくることを示している。 $70 \%$ 以上の伸線加工率の延性は, 介在物に直接の関係は なく，伸線による繊維状組織が主な原因となつてくる が，再焼ならし処理で伸線前と同様の関係に回復する.

\section{交献}

1) 内山 郁, 角田方衛：鉄と鋼, 57(1971), p. 1897

2 ）成田貴一，伊藤孝道：神戸製鋼技報，16(1966), p. $226 ; 17(1967)$, p. 53

3 ) T. $J$. Baker and $J \cdot A$. Charles: JISI, 210 (1972), p. 680

4 ) T. $J$. Baker and $J \cdot A$. Charles: JISI, 211 (1973), p. 187

5 ) 高田 寿, 金子晃司, 井上 毅, 木下修司：鉄と 鋼, 62(1976), p. 866

6 ) G. Bernard, $M$. Grumbach, and $F$. Moliexe: Metals Tech., 2 (1975), p. 512

7 ) $A . J$. Deardo and E. G. Hamburg: "Sulfide Inclusion in Steel" Proc. of an International Symposium, ASM (1974), p. 309

8 ) $H$. Takada, $K$. Kaneko, $T$. Inoue, and $S$. KinOSHita: ASTM STP 645, p. 335

$9) Y$. Nakamura, E.Takahashi, $N$. Hatsuoka, and $S$. Ashida: Wire J. 57 (1978), p. 110

10) C. E. Sims: Trans. AIME, 215 (1959), p. 367

11) $P . J . H$. Maunder and $J \cdot A$. Charles: JISI 206 (1968), p. 705

12) J.A. Charles and $I$. Ughiyama: JISI, 207 (1969), p. 979

13) 山口喜弘, 下畑隆司, 喜多壮大, 村上昌平, 淵野 好秀: 鉄と鋼, 62(1976), p.S 701 (一部未発表)

14) K. B. Gove and J.A. Charles: Metals Tech., 1 (1974), p. 425

15) $T . E$. Dunham and $R$. $F$. Hehemann: Met. Trans., 5 (1974), p. 2365

16）たとえば，小揮軍夫：「構造用鋼の非金属介在物 に関する諸問題」日本鉄鋼協会第 24,26 回西山記 念技術講座 (1974)，p. 127

17）武智 弘：日本金属学会会報, 12(1973), p. 845 